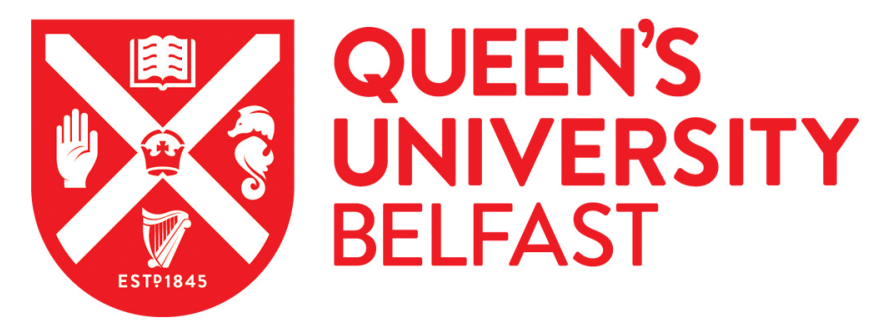

\title{
The management of workplace conflict: Contrasting pathways in the HRM literature.
}

Currie, D., Gormley, T., Roche, B., \& Teague, P. (2016). The management of workplace conflict: Contrasting pathways in the HRM literature. International Journal of Management Reviews.

https://doi.org/10.1111/ijmr.12107

Published in:

International Journal of Management Reviews

Document Version:

Peer reviewed version

Queen's University Belfast - Research Portal:

Link to publication record in Queen's University Belfast Research Portal

Publisher rights

(c) 2016 British Academy of Management and John Wiley \& Sons Ltd

This is the peer reviewed version of the following article: [Furrie, D., Gormley, T., Roche, B. and Teague, P. (2016), The Management of Workplace Conflict: Contrasting Pathways in the HRM Literature. International Journal of Management Reviews, which has been published in final form at http://onlinelibrary.wiley.com/wol1/doi/10.1111/ijmr.12107/full. This article may be used for non-commercial purposes in accordance with Wiley Terms and Conditions for Self-Archiving

\section{General rights}

Copyright for the publications made accessible via the Queen's University Belfast Research Portal is retained by the author(s) and / or other copyright owners and it is a condition of accessing these publications that users recognise and abide by the legal requirements associated with these rights.

\section{Take down policy}

The Research Portal is Queen's institutional repository that provides access to Queen's research output. Every effort has been made to ensure that content in the Research Portal does not infringe any person's rights, or applicable UK laws. If you discover content in the Research Portal that you believe breaches copyright or violates any law, please contact openaccess@qub.ac.uk. 
The Management of Workplace Conflict:

Contrasting Pathways in the HRM Literature 


\title{
The Management of Workplace Conflict: Contrasting Pathways in the HRM Literature
}

\begin{abstract}
Summary
This paper reviews the HRM literature on the management of workplace conflict. It suggests that workplace conflict is commonly viewed as a symptom of management failure in this literature: the notion that conflict may be intrinsic to the nature of work due to employees and managers having hard-to-reconcile competing interests is given short-shrift. At the same time, the paper identifies important differences in the literature, which we call pathways, about the best methods to management problems at the workplace. It is argued that four contrasting pathways can be detected in the literature with regard to how organizations approach innovating conflict management practices. Each pathway is examined fully and their respective strengths and weaknesses assessed fully.
\end{abstract}




\section{Introduction}

How workplace conflict is understood and how it is managed has changed over the past two decades. In the heyday of collective industrial relations, conflict at work was commonly viewed as something similar to the arrival of bad weather, not particularly welcomed, but inevitable nonetheless. This phlegmatic approach to workplace conflict was held by trade union representatives and personal managers alike, some even viewed the occasional industrial dispute as almost cathartic as it cleansed bad feelings between management and the workforce (Metcalf and Milner 1991). This view has been seriously challenged in recent times due to multiple factors, one of which is the rise of human resource management (HRM). In its endeavours to recast the professional identity of people management, to make it part of mainstream management, HRM views workplace conflict through a quite different cognitive lens: instead of adopting a phlegmatic approach to conflict at work, the vast bulk of HRM literature considers workplace conflict in an entirely negative link: a symptom of managerial failure that needs to be avoided as it distracts for the core goal of creating high performance organizations.

Although, there is a broad consensus in the HRM literature that workplace conflict is bad for organizations, there is no one view about how problems at work should be managed. A lack of agreement appears to exist on the extent to which the 'new' HRM view of workplace conflict has led to, or at least coincided with, the adoption of new policies and practices for the management of employment grievances and disputes. Even amongst those who argue that conflict management practices inside organizations need upgrading little consensus prevails about the nature of the innovations that should be diffused. The purpose of this paper is to assess how workplace conflict management is treated in the HRM literature. At the outset, we should say 
that our review is more or less confined to the HRM literature on the topic. We do not consider in any systematic manner the abundant studies of work and conflict completed by labour process scholars in the organizational studies field. Similarly, we do not seek to marshal in any throughgoing manner the vast industrial relations literature on workplace conflict. While we acknowledge important and rich research has been done in these respective areas, it would have been much too ambitious to try and review all these fields in the one paper. More positively, we feel that we have interrogated the considerable HRM-related literature on workplace conflict in a systematic and rigorous manner.

After suggesting that the HRM literature seeks to radically depart from the traditional industrial relations perspective on workplace conflict, we suggest that four distinctive pathways can be found in the literature about how to manage effectively problems inside organizations. The first pathway suggests that the best way firms can maintain a low conflict organizational environment is by adopting a strategic approach to workplace conflict management, which usually involves the diffusion of alternative dispute resolution (ADR) practices in some form or another. The second pathway stands in contrast to the first as it envisages firms updating conflict management procedures and practices through improvised and piecemeal changes. While HR managers who prefer to make improvised reforms to conflict management practices buy into the idea that workplace conflict should be viewed negatively, they are not inclined to adopt a strategic approach to conflict management innovations as they consider such changes leading to excessive organizational disruption. The third pathway envisages line managers playing a stronger role than hitherto in solving problems at work. The motivation behind this pathway is to promote informal conflict management. A fourth pathway seeks to prevent the incidence of workplace 
conflict largely by attempting to socialize it out of the organization. The principal method of doing so is through the systematic use of employee engagement and other 'organizational citizenship behaviour' practices. Before assessing these alternative approaches, some context setting remarks are made about conventional approaches to managing workplace conflict.

\section{The Changing Political Economy of Workplace Conflict}

Workplace conflict has always been defined as involving grievances and disputes between individual employees and their employer; among individuals; and between groups of employees, whether unionized or not, and their employer. In analytical terms grievances and disputes may arise from market relations (differences over the pricing of labour) and from managerial relations (differences over the exercise of management authority). A classical distinction in the literature on workplace conflict is that between 'collective conflict', involving employers and trade unions and ‘individual conflict', involving employers and individual employees.

To understand the genesis of current approaches to conflict management, it is important to examine the changing political economy of conflict management in workplaces. We do this in the next section of the paper.

\section{The management of workplace conflict in the era of collective industrial relations}

Conventionally, large industrial, commercial and public service organizations adopted formal disciplinary, grievance and dispute procedures, normally administered by the personnel, industrial relations function, to address workplace conflict (Williams 2011). These procedures normally prescribed formal steps to be followed by those involved in conflict (Lewin 1999; Slichter et al. 1960). First of all, employees were required to put in writing a grievance or register in some way a dispute. 
After submitting a formal grievance, the individual employee was normally formally represented: in unionized firms first by a trade union representative and then possibility by a trade union official if the grievance travels up the organizational hierarchy. Disputes affecting groups of employees in unionized firms were addressed at a first stage of procedure by engagement between representatives of the employees immediately affected and management at the relevant level. On the management side, progressively higher levels of managers become involved if the grievance or dispute was not resolved at the first or intermediary stage of the procedure. The last stage of the procedure almost invariably involved a formal adjudication of the grievance or dispute - either within the organization, for example by a panel of some kind, or, more commonly internationally, by some external agency such as a state conciliation, arbitration or adjudication agency.

Over the post-war period the overwhelming majority of large organizations came to adopt formalized procedures of this kind to address conflict (Slichter, et al. 1960; Wood et al 2014). In unionized organizations, formalized procedures make sense as they allowed for order and predictability, when HR managers and trade unions are obliged to interact with each other to resolve workplace problems of an individual or collective nature (Lewin 2001). While non-union organizations were frequently viewed as possessing more informal procedures to address conflict at work, they too have increasingly adopted formalized disciplinary and grievance procedures. Although formal disciplinary and grievance procedures have been adopted widely, how workplace conflict is viewed has changed decisively over the past number of decades. More than fifty years ago the discipline of industrial relations was invented to develop conflict management methods not only to help organizations avoid, or at least minimize, strikes and other forms of industrial action, but 
also to maintain the stability of the wider social and political order (Kaufman 1993; Piore 2011). A broad consensus emerged in the industrial relations literature about how to view workplace conflict. For the most part, this literature was fairly phlegmatic about the incidence of workplace conflict. Frequently, it is considered as virtually inevitable given that management and employees have competing as well as common interests (Edwards 1992). Moreover, a common view was that workplace conflict might actually be beneficial as it may have allowed management and unions to clear the air and rejuvenate their relationships (Lewin 1987).

The consensus in the industrial relations literature was that the effective management of workplace conflict was bound up with the development of collective industrial relations processes inside and outside the enterprise (Budd and Colvin 2104). These processes were considered necessary for a number of interrelated reasons. First of all, formal dispute resolution procedures that had trade unions at their centre were seen as the only effective way to counteract the power imbalance in the employment relationship. Employers were viewed as possessing greater resource advantages over employees, which militated against employees raising complaints and grievances against an employer on whom they were dependent for their living. Collective dispute resolution processes were seen as circumventing this problem, at least to some extent (Lewin 2001). Secondly, collective forms of dispute resolution were seen as a better way of ensuring that procedural fairness was built into practices used to address workplace conflict (Godard 2014a). Thirdly, the recognition of trade unions by firms was considered as helping prevent workplace conflict: the common argument put forward was that trade union representation created informal and formal voice mechanisms inside the firm that allowed managers and employees to air their complaints before they escalated into 
more serious problems (Edwards 1995). In other words, collective voice improved organizational loyalty and reduced organizational exit.

All in all, collective processes for solving workplace conflict are seen as part and parcel of a collective model of economic citizenship that reached an apex in during the decades following the $2^{\text {nd }}$ world war. Under this model, commonly known in the US as the 'New Deal Model', or in the UK as the 'pluralist model' and rooted in the reconstruction of labour market institutions following the Great Depression and the War (Kochan et al. 1985), trade unions entered into collective agreements with employers which involved balancing conflicting interests to ascribe rights and obligations to individual workers and enterprises in an effort to exclude serious conflict between them. It needs emphasizing personnel managers at this time largely bought into this model for managing workplace conflict. Co-mingling with trade unions to either smooth out niggling small scale problems or avert looming large-scale industrial unrest was grist-to-the-mill to many personnel managers. As a result of this activity, personnel managers too were largely phlegmatic about workplace conflict, viewing its incidence as almost inevitable, if not particularly welcome. Moreover, because personnel managers were so immersed in the resolution or prevention of workplace conflict, they became semi-detached from other parts of management. As a result, personnel managers remained at a distance from strategic corporate decision-making. Sometimes they were even treated with suspicion by senior managers who were concerned that they had got too close to trade unions: Batsone (1991) suggested that at times they were considered as the 'enemy within'.

Increasingly widely prevalent grievance and disputes procedures further reflected an underlying labour process that was commonly based on Fordist principles of mass production, involving 
narrowly defined jobs, organized into rigid grades, with uniform pay and salary structures (Piore 2011; Piore and Sabel 1984). The also in part reflected the dominance of a public policy tradition that was actively willing to provide employers, unions and employees engaged in conflict with state conciliation and labour court institutions of different kinds that comprised a public infrastructure to support conflict resolution above the level of the organization. The dominant approach to the management of workplace conflict also reflected the continuing significance of strike activity across most developed economies. During the 1960s and 1970s, strike activity in a number of countries indeed reached levels that threatened economic and social stability, while industrial conflict commonly spilled over into civil disorder, or was spearheaded by workplace union activists (Crouch and Pizzorno 1978).

\section{The management of workplace conflict following the rise of HRM and the Neo-Liberal Turn}

From the 1980s this model of conflict management began to unravel, as the conditions that had created and sustained it underwent significant change. First, the rise of human resource management (HRM) presented a challenge to the collective model of economic citizenship and inter alia collective processes for the resolution of workplace conflict. As an approach to managing people at work, HRM, in its current form, emerged in the USA in the early eighties (Kaufman 1993; Kochan et al. 1986). A core purpose of this approach is to recast the professional identity of personnel managers. Instead, of being primarily concerned with employee welfare, HRM views the main responsibility of people managers as contributing to organizational performance. Seeking to overhaul the professional raison d'être of people management in such a radical manner led to the creation of a new cognitive framework to view the appropriateness of established policies and practices across the entire spectrum of the HRM 
function. As a result, a battery of new policies has emerged to manage people at work: performance-related pay systems are figuring more prominently in the remuneration systems of companies, employee voice systems have been changed so that greater emphasis is placed on direct forms of representation, recruitment and selection policies have been upgraded and rebadged as talent management and so on.

Within the new HRM paradigm, workplace conflict has also been subject to some radical rethinking. For the most part, the human resource management literature tends not to use the concept of power to describe the employment relationship. As a result, from a HRM perspective there is no compelling case for collectivism to be the organising principle for a workplace conflict management system. Instead, employment disputes are seen as being capable of being resolved fairly and equitably in the absence of trade unions. Thus, on this view, non-union firms can set up procedures that ensure employees are treated fairly and with respect when a grievance is being investigated or a disciplinary action taken (Rowe 1997). The HRM literature also departs from the industrial relations approach to workplace conflict as it often sees employment grievances and dismissals as symptoms of managerial failure: workplace conflict is not seen as either desirable or inevitable, but something that needs to be managed and kept to be a minimum. The phlegmatic approach of old style personnel management towards employment disputes is discarded.

Thus, the industrial relations and human resource management literature present different visions of the nature and operation of workplace conflict management systems. It is not an exaggeration to say that the HRM literature seeks to recast the meaning of workplace conflict. In this view, 
workplace conflict is the manifestation of power relationships in a capitalist economy, but the result of individual failings on the part of particular managers or employees. Thus, on workplace conflict the new breed of HR managers stand apart from earlier generations of personal managers. Complementing changing views of workplace conflict and how it might effectively be managed was the dramatic decline in collective conflict that occurred across many advanced economies from the 1980s (Godard 2011a). The decline in collective conflict reflected a series of influences: declining trade union density; the continuing fall in levels of employment in strikeprone industries; the retreat of governments from Keynesian economic policies geared to minimizing unemployment and a neo-liberal turn in public policy favouring labour market deregulation and flexibility; the emergence of more open international trading regimes and possibly the suppression of workplace conflict from its traditional channels and modes of expression (Godard 2011a).

While the incidence and seriousness of collective conflict may have declined, collective disputes in open economies now often carry higher levels of risk for protagonists. In the words of one commentator, employers and unions engaging in work stoppages may now risk 'annihilation' through the loss of export or domestic markets to competitors (Brown 2014: 140). This puts a premium on searching out non-confrontational approaches to resolving conflict and on finding new ways of avoiding disputes (Brown 2014). One such way of resolving disputes by engaging in more co-operative forms of collective bargaining (so-called 'interest-based' bargaining) reflects a concern by employers and unions to negotiate more flexible forms of work organization and to promote mutual gains (Cutcher-Gershenfeld and Kochan 2004). So while the big industrial confrontations between employers and unions in the sixties and seventies may now 
be a thing of the past, workplace conflict still figures prominently in many organizations (Dix et al 2009). Nor have state conflict resolution agencies been immune from such changes, commonly responding to new pressures on their clients and users by expending more resources on the provision of various forms of 'proactive mediation' (Brown 2014).

The objective of developing forms of conflict resolution more in tune with new and more flexible - 'post-Fordist' - forms of work organization and labour processes has also been reported as a significant contributor` to the more general search for new ways of resolving conflict in workplaces (Kaminski 1999). This has also been influenced by the growth of a less deferential, more educated workforce, the intensification of work and the new emergence of new management practices such as performance management (see Rowe and Bendersky 2003). Nor have state conflict resolution agencies been immune from such changes, commonly responding to new pressures on their clients and users by expending more resources on the provision of various forms of 'proactive mediation' (Brown 2014).

At the same time there has been an equally dramatic rise in many countries in the incidence of individual employment grievances, driven in part by a massive growth in employment rights legislation (Colvin and Darbishire 2012; Estlund 2014; Roche et al. 2014) Organizations involved in employment rights cases before either civil courts or bodies like employment tribunals are almost certain to lose on procedural grounds if they do not possess formal disciplinary and grievance procedures (Hann and Teague 2012). Keeping on the right side of the law has not only prompted change within non-unionized firms, it has also done so in other organizations such as small firms, which otherwise have a preference for informal conflict management methods (Harris et al 2012). 
Finally the wider neo-liberal turn in economic and labour market policy is also mirrored in public policy initiatives in a number of countries seeking to promote or strengthen conflict management and resolution within organizations, with a view to encouraging parties to workplace conflict to become less reliant on state third-party agencies. This variously takes the form of support for workplace mediation programmes and incentivizing employers and unions to engage private facilitators (Van Gramberg et al. 2014; Rasmussen and Greenwoord 2014). Thus, a combination of influences both external and internal to the organization, rooted in the changing political economy of workplace conflict in advanced economies is giving rise to new forms of workplace conflict, coinciding with the emergence of a new cognitive framework within the HRM profession about how to understand employment disputes. Yet even though the common impulse across the HRM profession is to view workplace conflict in an entirely negative light, as deleterious for organizational performance and manager-employee relations, it is not at all clear that it has given rise to a widely agreed set of best practices to address workplace conflict. In fact, a number of contrasting pathways can be identified in the HRM literature about how to effectively address employment disputes and grievances, the character of which appears to be changing inside organizations.

\section{ADR and Strategic Conflict Management}

One pathway that can be found in the literature emphasizes the need for the diffusion of innovative conflict management strategies based on 'alternative dispute resolution' (ADR) principles (Rowe and Bendersky 2003). Although this literature is mostly USA in origin, it is heavily imbued with a 'universalism' associated with the rise of globalization that there is a set 
of 'best practice' procedures to manage workplace conflict. In this literature, the term ADR, as applied to the world of work, denotes procedures and mechanisms for conflict resolution that provide alternatives either to litigation or resort to administrative tribunals established under statute in such areas as equal opportunities and employment discrimination (Lipsky and Avgar 2004). The term also came to be associated with practices that represent alternatives to traditional grievance and dispute procedures and more specifically still with sets of procedures and mechanisms in non-union organizations such as workplace mediation, fact-finding, ombudsmen, arbitration and review panels comprised of managers or peer employees (Lipsey et al 2003). These mechanisms are sometimes bundled together in integrated 'conflict management systems', in which multiple forms of ADR, or so called 'interest-based' practices, take precedence over 'rights-based' fall-back procedures, such as formal grievance processes (Bendesrky 2007; 2003; Costantino and Sickles Merchant 1996; Roche and Teague 2014; 2012; Ury et al. 1988).

Procedures such as these, whether made available discretely or in systems, however are not the preserve of non-union firms and have become more common also in unionized employments particularly in the US public sector (Bingham 2009). Used in this sense, the term ADR has typically been applied to ways of handling conflict and disputes involving individual employees and often in the context of grievances and disputes surrounding individual employment rights. More recently the term has gained currency to denote also forms of dispute resolution which operate in conjunction with judicial processes. Here again the focus has been mainly on forms of ADR concerned with individual grievances (see Purcell 2010), but collective conflict and specifically disputes that arise in connection with collective bargaining also fall within the scope 
of this definition (Clark et al. 2012). These forms of ADR, which seek to eschew or postpone formal judicial or quasi-judicial hearings, may involve judges or other court-appointed officers or external experts. Thus a distinction is now recognized between 'judicial ADR' and 'nonjudicial ADR' - the latter term covering mechanisms for conflict resolution in the workplace, and sometimes extending to mechanisms of long vintage that fall outside the purview of legal regulation (Purcell 2010).

The term ADR is also now being applied to innovations in conflict management and resolution involving collective conflict in the workplace. Central here are innovations in collective bargaining and associated new dispute resolution mechanisms, such as 'interest based bargaining', 'collective mediation', fact-finding, the early facilitation of negotiations by an independent conciliator (a practice sometimes referred to as ‘assisted bargaining’ (ACAS 2009), brain-storming and related problem solving techniques, mediation by a party who may also be empowered to arbitrate ('med-arb’), mini-trials, arbitration proper and the proactive handling of change management. Some of these techniques may also be applied to group-based conflict in non-union firms, although non-union firms, especially of US origin, may resist recognizing conflict as a group phenomenon in any respect and may seek to disaggregate group conflict into individual grievances and deal with them only on that basis (Doherty 2011). Conflict management systems encompassing multiple forms of group or collective ADR are also contemplated in the literature, although less commonly than in the case of systems of this kind that address individual employment conflict (see for example Ury et al. 1988). The emergence of various forms of ADR in unionized firms aligned with collective bargaining provides a contrast not alone with resort to courts but also with long-standing dispute resolution processes, based on 
linear, multi-step stages that commonly culminate in resort to external third-party agencies or again to the courts. Table 1 seeks to represent the main conceptual domains of ADR in its current usage in the world of work.

[Table 1 about here]

One of key strands of the US literature on ADR is what will be referred to as the 'strategic paradigm'. In both the prescriptive and analytical literature on ADR there is a strong emphasis on how organizations should develop conflict management approaches and practices in a strategic manner by aligning these with organizations' competitive strategies and internal and external environments (Lipsey et al 2014). This perspective involves three analytical premises: conflict management innovations should be generally (1) vertically aligned with commercial strategy; (2) horizontally aligned with other conflict management practices and sets of HR practices, and (3) result from planning, deliberation and systemic change programmes (Costantinou and Sickles-Merchant 1996; Lipsky et al. 2003; 2012; 2014; Ury et al. 1988). Thus, this 'strategic paradigm' is of a piece with the dominant perspective on modern HRM posits that HR practices should be vertically aligned with commercial strategy and also horizontally aligned or mutually consistent.

This approach informs a recent empirical study of conflict management practices in US Fortune 1,000 firms. Here the adoption of ADR practices and conflict management systems is seen as a 'function of proactive and strategic decisions and not simply a reaction to external and internal pressures' (Lipsky et al. 2012: 5). In the same way, organizations are seen as 'not merely pushed 
or pressurized into adopting innovative conflict management practices' but 'rather an organization's conflict management approach is also a function of proactive, strategic decisionmaking factors' (Lipsky et al. 2014: 5). Major contributors to the strategic paradigm explicitly advocate the involvement of 'stakeholders' in the design of conflict management arrangements. Some prescribe what they refer to as 'interest-based conflict management systems design' (Costantinou and Sickles-Merchant 1996: ch. 4), while others advocate that unions be consulted with before any action is taken that affect their members, or that unions be invited to participate in the (re)design of conflict management arrangements (Lipsky et al. 2014: 160-1: Ury et al. 1988: 61-2).

Whatever processes may be involved in their adoption, virtually all commentaries in the literature point to a sharp rise in recent decades in the incidence of ADR practices focused on resolving individual employment grievances and disputes (Lipsky et al. 2012; Purcell 2010). Notwithstanding this it is also commonly observed that rates of resort by employees to particular forms of ADR are modest overall. Some of the factors responsible for this trend are also well identified, in particular an expansion in the volume of legislation conferring employment rights on people at work allied with a commensurate growth in people's determination to vindicate these rights. The result of these underlying developments has been a rise - dramatic in some countries - in the volume of cases referred to administrative and industrial tribunals and the courts, and a ratcheting up of the costs involved in the administration of tribunals and courts dealing with employment disputes. These costs fall both on states and on the litigants involved in disputes. A formalization of legal processes and a growing trend towards legal representation are widely reported. Damages awarded can also be substantial, especially in the United States. As 
Colvin (2012) has noted, the 'Gilmer' and 'Circuit City' judgments of the US Supreme Court have significantly contributed to the growing use of non-judicial ADR by allowing employers to specify in employment contracts that workplace dispute resolution processes must be used to settle any employment disputes that may arise. Another factor behind the rise of individual employment claims and disputes and the growing use of ADR is the decline in unionization and union power in workplaces. As a consequence of declining unionization a growing number of employees may have little choice other than to pursue workplace grievances, even grievances that may essentially be collective in their genesis and nature, as individual claims. In some countries, especially the UK, it has been observed that the decline of unionization and collective bargaining has been associated with the transference of workplace conflict from strikes and other collective expressions of conflict to a range of individual manifestations of conflict (Dix et al. 2009). On the management side, the advent of HRM as an influential paradigm is also seen to be an important influence on the growth of ADR mechanisms of various kinds for handling individual conflict (see Lipsky et al. 2003; Roche and Teague 2011). Innovative forms of dispute resolution may indeed represent an extension into the realm of conflict management of the basic principles and postulates informing HRM policies more generally in firms. A strategy of engaging in 'union substitution' also sometimes seems to be a potent influence on the use of individual forms of ADR, especially in the US.

The advent of collective forms of ADR reflects somewhat different if also sometimes overlapping sets of influences. There has been a secular decline in levels of industrial conflict and especially in the volume of strike activity in many countries. The emergence of innovative mechanisms for resolving collective conflict and disputes is not in any direct or simple way 
related therefore to concerns about industrial conflict and its consequences. Collective agreements in some countries are not generally regarded as legally binding and so no financial penalties arise in the event of breaches of collective contracts. Even in countries where collective bargaining agreements carry legal force, sanctions or penalties have not been reported as an influence on innovations in conflict resolution. The key driver behind the growth in collective ADR is the search for speedier and more flexible forms of dispute resolution and negotiation than available through traditional dispute and grievances procedures, or through established modes of negotiation or external conciliation, adjudication and arbitration (Lipsky et al. 2003). Related to this is a growing concern on the part of employers, embraced with varying degrees of enthusiasm by unions, to foster a more co-operative climate of employment relations. This objective is seen to be well served by moving away from traditional procedures for conflict resolution, which may be viewed as an institutional expression of low-trust and adversarial postures on both sides. Such developments may reflect deeper forces such as globalization and growing economic openness, new competitive priorities focused on innovation and quality enhancement and allied innovations in manufacturing technologies, service delivery and work organization. The rise of employer-union workplace partnership initiatives, reported as a significant trend in some Anglo-Saxon countries from the 1990s, has also been associated with the advent of new forms of collective ADR like interest-based bargaining, problem solving factfinding and mediation (Kaminski 1999; Kochan et al. 2009).

Colvin (2012) reports in the case of the US that greater diversity exists in ADR in procedures for conflict resolution in non-union companies than in unionized companies, where quite standard procedures still dominate the picture. This is likely to be in line with the pattern for other 
countries. Purcell's (2010) study of individual ADR in European countries reports considerable cross-national variation in both forms and frequency around a secular rise in the incidence of ADR. The dispute resolution profiles or systems of different countries, especially as they involve ADR, and the forces accounting for diversity, have yet to be studied systematically, but Colvin (2012) urges an approach to ADR which treats the practices involved, and trends therein, as reflective of broader systemic features and trends with respect to countries' conflict resolution arrangements.

Colvin (2012) reveals that the US may well have one of the most individualized dispute resolution systems of all advanced economies in that non-union procedures and practices affect significantly more employees - estimated as twice as many - as the grievance systems associated with collective bargaining. Other countries may be headed in a similar direction, as evident, for example, from Benson’s (2012) portrayal of Japan. In the Japanese case, the long recession since the 1990s combined with a decline in unionization and collective bargaining has led to a growth in forms of dispute resolution - both non-judicial and judicial - above the level of the workplace, as well as to a growth in individual employment grievances and disputes. In the Irish case, Roche and Teague (2012) report a higher incidence in firms of forms of non-judicial group and collective ADR in Ireland than individual ADR practices and mechanisms. This reflects on the one hand the absence of mandatory firm-level individual dispute resolution, such as initiated in the US by the Gilmer and Circuit City judgements, and the much lower overall awards of statutory tribunals dealing with unfair dismissals, redundancy, equality and other employment rights. It also reflects on the other hand the relatively higher level of unionization in the Irish case and the competitive pressures on unionized firms to find speedier and less adversarial ways 
of resolving disputes. Clark et al. (2012) compare the UK and France and show how different modes of conflict resolution, including ADR, are rooted in different legal and administrative traditions: the justice system in France and arms-length independent government agencies in the UK. McAndrew (2012) traces the development of collective ADR in New Zealand in the changing laws surrounding collective bargaining and their wider context in New Zealand politics. Finally, Forsyth (2012) attributes the continuing dominance of public agencies in dispute resolution in Australia and the limited incidence of workplace-level ADR to the historical and current features of Australia's national dispute resolution traditions and laws.

Whether assessed discretely, or bundled together in integrated conflict management systems, ADR practices are commonly associated in the literature with a range of outcomes. Mediation, as already highlighted, is found to have a series of positive effects for both employers and employees (for a review of the international evidence see Latreille 2011). A variety of other forms of ADR used in the US and Australia for handling disputes involving individuals have been assessed as benefiting employees and their employers (Ewing 1989; Van Gramberg 2006). In the case of outcomes of primary importance for employers, ADR-led conflict management systems, focused in the main on resolving individual employment conflict, have been associated by commentators with higher productivity, lower conflict-related costs, more adaptive organizations and higher organizational morale and commitment (Bingham and Chachere 1999; Lynch 2001). Links with lower absence and lower labour turnover rates have also been cited, as have links between ADR-led conflict management systems in non-union firms and union avoidance (Bingham and Chachere 1999; Lipsky and Avgar 2004). They have also been associated with outcomes of importance for employees, such as procedural and substantive 
justice in the workplace, higher work satisfaction and a greater capacity to resolve potentially destructive conflict (Bendersky 2007; 2003; Conbere 2001; Lynch 2001).

Interest-based bargaining and associated problem-solving practices are also reported to have been positively received by employees and to be associated with a range of beneficial outcomes for employees, employers and trade unions (Kochan et al. 2009). Much of the relevant research draws on case studies and sometimes on paradigmatic or exemplary cases such as the US Postal Service's REDRESS mediation programme (Bingham and Pitts 2002), or the partnership initiatives at Saturn or Kaiser Permanente (Rubinstein and Kochan 2001; Kochan et al. 2009). Cutcher-Gershenfeld (2003), on the other hand, presents survey data on interest-based bargaining in the US. Over a quarter to a fifth of union and management negotiators expressed a preference for interest-based bargaining over traditional collective bargaining and those with experience of the technique were more likely to report that bargaining relationships with their interlocutors were improving.

Overall, the concept of alternative dispute resolution (ADR) has received considerable exposure in the workplace conflict management literature and for some it represents the basis of a high quality conflict management system as it seeks to involve the parties to a dispute in a consensual process that empowers them to solve their differences to their mutual satisfaction (Cropanzano et al 2008). ADR-inspired innovative approaches to conflict management envisage a qualitatively different set of practices or mechanisms for managing workplace conflict that represent alternatives to traditional grievances and disputes procedures designed on the basis of classical adversarial precepts and assumptions (Folger and Cropanzano 1998). Most of the work done on 
the extent to which organizations are diffusing ADR practices to manage workplaces, especially in the manner proposed by the dominant strategic paradigm, has been in the United States and has focused on that country's largest corporations. The evidence appears to suggest that there has been a fairly widespread move by organizations to adopt at least some form of ADR (Lipsky et al 2014). However, the incidence of the diffusion of workplace ADR practices in other countries is patchy if not low (see Teague, Roche and Hahn 2012). This begs the question whether ADR approaches to workplace conflict is a uniquely American invention. What gives weight to this view is that the matter of innovation workplace conflict practices, particularly those that are infused with ADR principles, is only sparsely treated in the new strategic HRM literature. Thus, it remains to be seen how extensive these practices will be introduced over the course of time across countries.

\section{Improvisers and Workplace Conflict}

Another view in the literature, which stands in sharp contrast to the strategic paradigm, posits that organizations typically make improvised and piecemeal changes to conflict management procedures and practices when faced with specific problems, showing little appetite for introducing systematic changes on strategic grounds (Roche et al 2012). Thus on this view, the internal changes occurring within the HRM profession alongside the large scale shift in the nature of workplace conflict, has not triggered a radical departure from conventional workplace management practices (Roche et al 2012). A number of surveys have found that organizations have not changed their approach to workplace management in any far reaching way (Roche and Teague 2011 and Wood et al 2014). Although there is evidence of some firms introducing small scale changes or modifications, the trend appears to be that these are made in a reactive, ad-hoc 
way, normally in response to a particular problem or development. Moreover, when introducing new practices, HR managers seem to do so in a manner that does not disrupt too much conventional processes (Roche and Teague 2014).

Thus, HR managers appear keen to stay as much as possible with formal disciplinary and grievance procedures backed up with some type of informal problem solving, only occasionally introducing new practices such as mediation or some form of interest-based bargaining. In other words, HR managers are adopting an incremental approach to workplace conflict management innovation. On this view, the HR profession may be framing workplace conflict in an entirely new light, but in practices HR managers are reluctant to follow some type of best way mentality. Instead, they pursue a best fit mentality so as not to disrupt established social relations inside the organization when upgrading conflict management policies.

A number of interrelated factors may lie behind the apparent reluctance of HR managers to move away from conventional conflict management practices even though they may have internalized the negative view of conflict at work. One argument in the literature is that even though HRM has become the dominant method for managing people at work, HR managers tend not to use a strategic approach to managing people in the sense of seeking out so-called 'best practice' options and scrupulously assessing the most optimal alternative for their organization (Marchington and Grugulis 2000 and Caldwell 2008). Instead, HR managers are seen as locked into tried and tested ways of doing things. As a result, the improvised approach to workplace conflict management innovation is a by-product of HR managers shying away from adopting radically new policies fearful of the organizational uncertainty that may be generated 
and eager to avoid the transition costs involved in switching conflict management regimes (Sydow et al 2009).

A second factor explaining why HR managers may prefer to stay with traditional approaches to conflict management is that they do not see the need for radical change. Some studies have found that although managers may grumble about various aspects of workplace conflict management, the great majority considered it not to be a problem and under control (Roche and Teague 2014). Today, few managers consider workplace conflict to have the capacity to destabilize organizations in any serious manner. With conflict being considered less menacing, few managers see the need to move radically away from conventional dispute resolution practices (Fevre et al 2012).

A third factor that has been identified as encouraging the improvised approach to workplace conflict management innovation is survey evidence that suggests that while managers consider it important to resolve problems quickly and effectively, they also believe that that no silver bullet exists for the management of workplace conflict (Roche at al 2011). The prevailing view across managers is that while some organizations might be better at reducing conflict than others, there is no one practice or group of practices that would eliminate it entirely. Conflict is considered to be an ever present aspect of organizational life and the function of management is to address it as effectively as possible (Ackroyd 2008). This view militates against HR managers adopting far reaching reform of conflict management practices. 
Although managers adopt a cautious approach to conflict management innovations, conventional dispute resolution practices have been upgraded or amended to some degree, which suggests that organizations cannot immunize themselves fully from external and internal influences that precipitate the need for some form of adjustment to dispute resolution practices (Pfeffer 2007). Perhaps, the most notable change that has taken place over the past decade has been the adoption of mediation: Wood et al (2014) use the recent Workplace Employment Relations Survey to estimate that about 17 per cent of workplaces in Great Britain have adopted mediation in some form or another. In the literature, mediation is regarded as an appropriate method to address new emerging forms of workplace conflict such as 'relationship-based' conflict have has risen due to the more widespread use of teamwork and performance management. Governments across the Anglo-American world have been actively encouraging organizations to adopt mediation as they consider it as facilitating the early resolution of disputes, thus preventing these mutating into litigation (Colvin and Darbishire 2013).

The manner in which mediation is being diffused by organizations may highlight the inbuilt reluctance on HR managers to adopt new conflict management policies. A body of research, mostly USA in origin, sets out the benefits that await organizations should they use mediation to address workplace conflict, including high settlement rates, improved conflict management by individual managers, the early resolution of disputes, which led to substantial savings in terms of staff time and cost, and high participant satisfaction rates (see Bingham, 2004, Colvin 2004 and Nesbit et al., 2012). Similar findings were found in a number of UK studies (Saundry and Wibberley, 2012a and Latreille 2011). Some research suggests that mediation can even have a transformative effect on employment relations inside organization by acting as a catalyst for 
informal conflict resolution and new forms of trust being formed between managers and employees and their representatives (Bingham 2009 and Saundry et al 2013) However, these favourable assessments beg the question: if mediation brings such positive benefits why it is adopted only by a minority of organizations? One plausible explanation is that managers are tied to tried-and-tested methods for solving disputes and as a result shy away from adopting new conflict management practices. Thus, on this view HR managers at best are reluctant innovators when it comes to workplace conflict management.

\section{Proactive Line Managers and Workplace Conflict Management}

A third approach to managing workplace conflict that can be detected in the literature emphasizes the role of line managers. Although line managers have always been involved in problem-solving, their conflict management functions have become enlarged and more formalized (Purcell 2014). To a large extent, this change is due to line managers acquiring an elevated HR role inside organizations due to the widespread adoption of the 'business partner model' of people management (Ulrich 1997). The aim of this model is to make HRM more strategic in orientation - ensuring that the HR function gets closer to the main decision-making arenas inside the organization. The model requires a double organizational movement to facilitate strategic HRM (Paauwe et al. 2013). One involves senior HR managers being incorporated into the core strategic decision-making bodies of the organization thus centralizing key features of the HR function. The other involves delegating responsibility for implementing a battery of HRM policies to other tiers of management, particularly line managers and supervisors. Increasing the $\mathrm{HR}$ role of line managers results in them acquiring greater responsibility for addressing workplace conflict (Brewster and Soderstrom 1994). 
Line managers can assist the resolution of problems at work in various ways. First of all, line managers can help prevent workplace conflict by performing a mentoring and coaching role. This involves line managers interacting with employees to help them develop their skills and competences and to find their way in organizations (Floyd and Wooldridge 1997). Coaching and mentoring activity provides line managers with the opportunity to identify whether employees are unhappy with any aspects of the organization or if they are encountering other workplace problems. Secondly, line managers can also address workplace conflict by engaging in 'sensemaking activity' (Weick et al 2005). Sense-making is the way managers come to understand the strengths and weaknesses of the organization and its employees. It involves line managers doing two things. One is identifying those activities and processes that encourage trust and cooperation at the workplace. The other is making early effective interventions to stave off conflict: line managers are in the position to read unfolding events so that they can react quickly to potential problems that are brewing (Rouleau 2005). Thus, line managers help prevent workplace conflict by performing a coaching and mentoring role inside the organization.

Line managers can also play an active role in the resolution of workplace conflict. A consensus exists in the specialized literature that it is preferable to solve workplace problems as close as possible to the point of origin (Ury et al 1988). Because they interact with employees on an ongoing basis, line managers and supervisors are ideally positioned to perform such a problemsolving role. By intervening quickly after a problem arises, line managers are best placed to broker an informal settlement to a conflict or problem that is hopefully to the satisfaction of all involved parties (Purcell and Hutchinson 2003). By resolving problems informally, line 
managers allow the organization to use formal conflict management procedures sparingly, which has the effect of deterring employers from using them: with only being used intermittently, it becomes a bigger deal for employees to evoke formal procedures.

On paper, the rationale for greater line manager involvement in conflict management is impeccable. But several studies suggest that realizing these paper benefits in practice is far from straightforward. Like other HR policies, line managers may not implement conflict management practices optimally (Purcell 2014b and Cunningham and Hyman 1999). In some instances, line managers may consider conflict management secondary to their role of completing operational tasks. As a result, they may neither have the motivation nor commitment to fulfil a conflict management role (see Maxwell and Watson 2006, and McGovern et al 1997). Other studies suggest that line managers may not share the same outlook or even culture as HRM managers on conflict management and thus may not implement these policies in the manner that was intended (Wright et al 2001 and Purcell and Hutchinson 2007). To ensure that line managers take their responsibilities seriously, organizations could build conflict management into their performance appraisal and monitor how effectively they solve problems by collecting data on conflict management. But the evidence is that only a small minority of organizations follow either of these practices: most organizations do not formally appraise how line managers resolve problems nor monitor how effectively internal conflict is resolved (Teague and Roche 2012). Another problem is that line managers are likely to require formal training before they can perform a conflict management role satisfactorily: they have to be good listeners and communicators; they need the ability to survey all possible solutions to a problem; they need to act in a manner that secures the trust of those involved in the conflict (Whittaker and Marchington 2003). But 
evidence suggests that the training and support provided to line management on conflict management is rudimentary (Teague and Roche 2012).

Some studies suggest that an even deeper problem lies with policies that aim to increase the role of line managers in conflict management (Saundry et al 2014). In particular, it is suggested that line managers through their actions may be exacerbating rather than reducing conflict at work (Fevre et al 2012; Purcell 2014a). On this view, the potential for line managers to be the source of workplace conflict has increased considerably as organizations strive for even better competitiveness. Line managers are facing immense pressure to ensure that employees deliver on performance targets (Guest 2011). Invariably, this involves line managers exhorting employees to intensify their work efforts, which is frequently the source of conflict and disputes in organizations. As a result, line managers are as likely to be the promulgator of workplace conflict as much as the resolver of such problems. The problem for many organizations that have enacted the 'business partner model' of HRM is that they are no longer likely to have any HR practitioners at the workplace who could act as an intermediary when problems arise between line managers and employees (Guest and King 2004). Thus, requiring line managers simultaneously to be the drivers of performance and the key organizational problem-solvers could ironically make some forms of workplace conflict more difficult to resolve, if they are actually detected in the first place (Marchington 2009). Saundry and Wibberley (2012b) refer to this problem as the resolution gap.

Overall, the literature on the role of line managers in the resolution of workplace conflict points in two directions. In one direction, a strong case can be found for line managers playing a role in 
addressing problems at work. In the other direction, the evidence suggests that in practice this role is unlikely to be problem free. The result is that organizations may find themselves trapped in difficult-to-solve conundrum: on the one hand, line managers may have become pivotal to the resolution of workplace, but on the other hand, they may not have the wherewithal to perform this role effectively.

\section{Preventing Workplace Conflict}

A fourth stand of literature argues that the most effective way to address workplace conflict is to prevent it emerging in the first place. As we have seen, a common argument made in the industrial relations literature is that workplace conflict can be resolved satisfactorily without recourse to formal procedures, through the use of informal, behind-the-scenes discussions between trade unions representatives and managers (Budd and Colvin 2104). In the wake of the decline of trade union density almost everywhere, an argument frequently made in this literature is that a 'representation gap' has emerged in many organizations, making them more vulnerable to higher incidences of conflict (Antcliff and Saundry 2009 Burgess et al., 2000; Knight and Latreille, 2000). Other related arguments can be found in the industrial relations literature. A number of interesting studies (Avgar 2010 and Avgar et al 2014) suggests that organizations with high levels of social capital are less likely handle to experience workplace conflict. By building trust and cooperation amongst employees and between managers and employees, organizational social capital reduces the extent to which workplace conflict has had an adverse impact on workplace relations. 
A distinctive approach to the prevention of workplace conflict management has emerged recently in the HRM literature. The main thrust of this literature is effectively to prevent conflict by socializing it out of the organization. This involves fostering a psychological alignment between employees and their place of work, which leads then to identifying with the purpose, mission and values of the organisation (Beer 2009). It is seen as creating organizational citizenship behaviour that repudiates 'negative' forms of conflict (Sparrow, 2013). Although defined in different ways, studies of organizational citizenship behaviour tend to focus on broadly similar issues. Podsakoff et al (2000) identify seven recurring themes in the related literature: helping behaviour; sportsmanship; organizational loyalty; organizational compliance; individual initiative; civic virtue; and self-development. As can be gleaned from these themes, organizational citizenship behaviour is about employees coming to view their own career advancement as being intertwined with the success of their employing organization. Thus, it is about employees who willingly help each other, tolerate day-to-day workplace hassles, support, and where required, defend the mission of the organization, internalize organizational rules and procedures, 'go above and beyond the call of duty' to advance organizational performance, and strive to develop their own attributes and abilities (Godard 2014b).

Thus, organizational citizenship behaviour manifests itself in employees having a positive commitment to the organization and displaying on-going discretionary effort to help the organization achieve its goals. A key goal of strategic HRM is to elicit this behaviour by following a variety of employee engagement policies (Ulrich 1997). Employee engagement policies are highly fashionable and a large literature has emerged on the topic (see MacLeod and Clarke 2009, and Truss et al 2013). These policies seek to engender a belief system in the 
organization that orients employees towards the mission of the organization by defining it for them and identifying its salient features (Arrowsmith, and Parker 2013). A battery of interlinked practices and processes are pursued to create cognitive lenses through which employees come to understand the organizational values and behaviour they are expected to uphold (Bowen and Ostroff 2004). The goal is to create a symbiosis between organizational purpose and what employees find meaningful in their day-to-day work tasks.

Many organizations may not pursue employee engagement policies in an integrated manner (MacLeod and Clarke 2009). Yet as an approach to managing people, it is proving hugely influential. For the most part, workplace conflict in this approach is seen as getting in the way of building organizational loyalty and commitment (Purcell 2014b). A study of conflict management systems in 92 subsidiaries of non-union multinationals in Ireland found this approach prevailing in the overwhelming majority of organizations (Doherty and Teague 2011). The study found that: (1) managers had a deep antipathy to the 'conflict management' paradigm; (2) conflict management was not considered part of the strategic HR function; (3) a 'business case’ did not exist for ADR-style workplace conflict management innovations; (4) managers did not want the language of conflict or conflict management to be used in the organisation and also actively sought to expunge conflict from the vocabulary of the organisation. Thus, workplace conflict was considered incongruent with the key responsibility of the HR function to create a sense of obligation amongst employees to contribute something to the core mission of the organization. As a result, concerted effort was made across subsidiaries to push conflict to the margins of the organization, even at times framing it almost as dissident behaviour. Conflict is prevented by socializing it out of the organization. 
Thus, the main message from this part of the literature is that the task of HR managers is neither to stay with tried-and-tested conflict procedures nor adopt ADR-style innovative conflict management strategies, but to pursue a range of interrelated policies that radically reduces the incidence of workplace conflict. The strategy is to cultivate a positive attachment between employees and the organization so that conflict is considered outside the realm of everyday organizational life (Godard 2014b and Purcell 2014b). It is an approach to conflict management that is probably more suited to non-union organizations but not confined to these. For the most part, procedures for handling grievances and disputes in non-union firms are traditionally less formalized than in unionized firms (Lewin 2004). This is probably still true and as a result, the organizational environment in non-union firms is more conducive to a strategy of socializing conflict out of the workplace. More formidable institutional obstacles stand in the way of such a strategy in unionized firms (Colvin 2003).

[Figure 1 about here]

\section{Conclusions}

This paper argues that four contrasting pathways to managing workplace conflict managementoutlined in Figure 1 exist in the HR literature. Yet even though each envisages quite different methods for resolving workplace problems, it is important to recognize that common underlying assumptions tie together the four pathways. Each pathway moves away from the phlegmatic view of workplace conflict that held sway within the personnel management profession several decades ago; views workplace conflict as a symptom of management failure; repudiates the idea that workplace conflict is rooted in fundamentally competing interests of employees and organizations; and considers workplace conflict as pathological, usually the result of bad or inept 
behaviour on the part of individual employees or managers or some misguided piece of administrative or organizational practice.

\section{References}

Ackroyd, S. (2008) Organizational Conflict in C. Cooper and J.Barling (eds) Handbook of Organisational Behaviour, London: Sage

Advisory Conciliation and Arbitration Service (Acas) (2009) The Alchemy of Dispute Resolution - the Role of Collective Conciliation, London: Acas Policy Discussion Papers.

Antcliff, V. and Saundry R (2009) Accompaniment, Workplace Representation and Disciplinary Outcomes in British Workplaces - Just a Formality? British Journal of Industrial Relations, 47:1, 100-121.

Anderson, V., Rayner, C. and Schyns, B. (2009) Coaching at the Sharp End: The role of Line Managers in Coaching at Work, London: CIPD

Arrowsmith, J. and Parker, J. (2013) The meaning of 'employee engagement' for the values and roles of the HRM function. International Journal of Human Resource Management, 24: pp 2692-2712

Avgar, A. (2010) Negotiated capital: Conflict, its management, and workplace social capital, the International Journal of Conflict Management, 21:3, 236-259

Avgar, A. C., Kyung Lee E. and Chung W., (2014) Conflict in context: Conflict, employee outcomes, and the moderating role of social capital and discretion, International Journal of Conflict Management 25: 3:276-303 
Batstone, E., (1980), 'What have personnel managers done for industrial relations, Personnel Management, 12, 36-39

Beer, M. (2009), High Commitment High Performance: How to Build a Resilient Organization for Sustained Advantage, San Francisco: Jossey-Bass.

Bendersky, C. (2003) Organizational Dispute Resolution Systems: a Complementarities Model. Academy of Management Review, 28 4: 643-56.

Bendersky, C. (2007) Complementarities in organizational dispute resolution systems: how system characteristics affect individuals' conflict experiences. Industrial and labor Relations Review, 60: 204-24.

Benson, J. (2012) Alternative Dispute Resolution in Japan: The Rise of Individualism. International Journal of Human Resource Management, 23: 511-527.

Bingham L. (2004) 'Employment Dispute Resolution: The case for mediation', Conflict Resolution Quarterly, 22:1-2, 145-174.

Bingham, L. (2009) 'The politics of evaluation. Lessons learned from the evaluation of workplace dispute resolution programs', Labor and Employment Relations Association Series, Proceedings from the 59th Annual Meeting

Bingham, L. and Chachere, D. (1999) Dispute Resolution in Employment: The Need for Research in Eaton, A. E. and Keefe, J. H. (eds), Employment Dispute Resolution and Worker Rights in the Changing Workplace. Champaign, IL: Industrial Relations Research Association: 95-136

Bingham, L.B. and Pitts, D. (2002) Highlight of Mediation at Work: Studies of the National REDRESS Evaluation Project. Negotiation Journal, 18: 135-46.

Bowen, D. and Ostroff, C. (2004) Understanding the HRM-Firm Performance Linkages: The Role of the Strength of the HRM System. Academy of Management Review, 29: 203-221

Brewster, C. and Soderstrom M. (1994) Human resources and line management. in Brewster C. and Hegewisch A., Policy and Practice in European Human Resource Management, London: Routledge

Budd, J. and Colvin. A. (2014) The Goals and Assumptions of Conflict Management in Organizations. in W. K. Roche, P. Teague and A.J. S. Colvin, The Oxford Handbook of Conflict Management in Organizations, Oxford, Oxford University Press

Burgess, S. Propper, C. and Wilson, D. (2000) Explaining the Growth in the Number of Applications to Industrial Tribunals 1972-1997, Employment Relations Research Series, No 10. London: Department of Trade and Industry. 
Caldwell, R. (2008) HR Business Partner Competency Models: Recontextualising Effectiveness. Human Resource Management Journal, 18: 275-294.

Clark N, Contrepois S. and Jefferys S. (2012) Collective and individual alternative dispute resolution in France and Britain. International Journal of Human Resource Management, 23: 550-566

Colling, T. (2004) No Claim, No Pain? The Privatization of Dispute Resolution in Britain’, Economic and Industrial Democracy, 25:4, 555-579

Colvin, A. J. S. (2003) The Dual Transformation of Workplace Dispute Resolution. Industrial Relations, 42:712-735.

Colvin, A.J.S. (2012) American Workplace Dispute Resolution in the Individual Rights Era. International Journal of Human Resource Management: 23: 459-475

Colvin, A.J.S. and Darbishire, O. (2013) Convergence in Industrial Relations Institutions: The Emerging Anglo-American Model? Industrial and Labour Relations Review, 66 (5): 1045-1075.

Combs, J., Liu, Y. Hall, Ketchen, D. (2006) How Much Do High-Performance Work Practices matter? A Meta-Analysis of Their Effects on Organisational Performance. Personnel Psychology, 59: 501-28.

Conbere, J.P. (2001) Theory Building for Conflict Management System Design. Conflict Resolution Quarterly, 19: 215-36.

Costantino, C. And Merchant C. (1996). Designing conflict management systems: A guide to creating productive and healthy organisations. San Francisco, CA: Jossey Bass

Cropanzano, R., Bowen, D. E. and Gilliland S. W. (2008) The Management of Organizational Justice. Academy of Management Perspectives, 3: 35-47

Cunningham, I. and Hyman, J. (1999) Devolving human resource responsibilities to the line: beginning of the end or a new beginning for personnel? Personnel Review, 28: 9-27

Cutcher-Gershenfeld, J. (2002) How Process Matters: a Five-Phase Model for Examining Interest-Based Bargaining in T.A. Kochan and D. Lipsky (eds.), Negotiations and Change: from the Workplace to Society, Ithaca: Cornell University Press.

Cutcher Gershenfeld, J., Kochan, T., Barrett B. and Ferguson, J-P. (2007) Collective Bargaining in the Twenty-First Century: A Negotiation Institution at Risk Negotiation Journal, 23: 249 65

Dix, G., Sisson, K. \& Forth, J. (2009) Conflict at Work: the Changing Pattern of Disputes, in W. Brown, A. Bryson, J. Forth and K. Whitfield (Eds.), The Evolution of the Modern Workplace, Cambridge: Cambridge University Press: 176-200 
Doherty L. and Teague P. (2011) Conflict Management Systems in Non-Union Multinationals in the Republic of Ireland. International Journal of Human Resource Management, 21: 57-71

Doherty, L. (2011) Conflict Management Systems in Subsidiaries of Non-Union Multinational Organizations Located in the Republic of Ireland, presentation to Labour Relations Commission Symposium, 'Building Better Employment Relations', Dublin: Croke Park Conference Centre, 23 February.

Edwards, P.K. (1995) 'Human resource management, union voice and the use of discipline: an analysis of WIRS3', Industrial Relations Journal, 26:3: 204-220

Estlund, C. (2014) The Development of Employment Rights and the Management of Workplace Conflict in W. K. Roche, P. Teague and A.J. S. Colvin, The Oxford Handbook of Conflict Management in Organizations, Oxford, Oxford University Press

Ewing, D.E. (1989) Justice on the Job: Resolving Grievances in the Nonunion Workplace, Boston Mass.: Harvard Business School Press.

Fevre, R., Lewis D., Robinson A. and Jones T. (2012) Trouble at work. London: Bloomsbury Academic

Floyd, S, and Wooldridge, B. (1997) Middle Management Strategic Influence and Organisational Performance, Journal of Management Studies, 34: pp 465-485

Folger, R., and Cropanzano, R. (1998) Organizational Justice and Human Resource Management, Beverly Hills, CA: Sage

Forsyth A. (2012) Workplace conflict resolution in Australia: the dominance of the public dispute resolution framework and the limited role of ADR. International Journal of Human Resource Management 23: 476-494

Gratton, L., Hope-Hailey V., Stiles, P. And Truss C. (eds), (1999) Strategic Human Resource Management, Oxford: Oxford University Press

Godard, J. (2014a) Conflict in Capitalism in W. K. Roche, P. Teague and A.J. S. Colvin, The Oxford Handbook of Conflict Management in Organizations, Oxford, Oxford University Press.

Godard, J. (2014b), The psychologisation of employment relations? Human Resource Management Journal, 24: 1-18

Guest, D. (2011) Human resource management and performance: still searching for some answers. Human Resource Management Journal, 21:3 - 13

Guest, D. and King Z. (2004) Power, Innovation and Problem-Solving: The Personnel Managers’ Three Steps to Heaven? in Journal of Management Studies 41: 401-423 
Hales, C. (2005) Rooted in supervision, branching into management: continuity and change in the role of first-line manager. Journal of Management Studies, 42: 471-506.

Hann, D. and Teague, P. (2012) The Changing Role of Employment Tribunals: The Case of the Employment Appeals Tribunal in Ireland, Economic and Industrial Democracy, Vol. 33:3: 531549

Harris, L., Tuckman A. and Snook J. (2012) Supporting workplace dispute resolution in smaller businesses: policy perspectives and operational realities, International Journal of Human Resource Management, 23: 607-623

Horibe, K (1999) Managing Knowledge Workers: New Skills and New Attitudes to Unlock the Intellectual Capital in Your Organisation, Oxford: Blackwell Publishing

Kaminski, M. (1999) New Forms of Work Organisation and Their Impact on Organisational Grievance Procedures, in A. Eaton, J.H. Keefe (eds), Employment Dispute resolution and Worker Rights in the Changing Workplace, Illinois: Industrial Relations Research Association: 219-246

Keenoy, T. (2005) HRM as Hologram: A Polemic in Cary Cooper and William H. Starbuck (eds) Work and Workers, London \& New York; Sage Publications: 146-62

Jones, C. and Saundry, R. (2012) The Practice of Discipline: Evaluating the Roles and Relationship between Managers and HR Professionals, Human Resource Management Journal, 22:3: 252-266

Kochan T. (2004) Restoring Trust in the Human Resource Management Profession, Asia Pacific Journal of Human Resources, 42: 32-146

Kochan, T.A., Eaton, A., McKersie, R.B., Adler, P.S. (2009) Healing Together: The Labor Management Partnership at Kaiser Permanente, Ithaca: Cornell University Press.

Knight, K.G. and Latreille, P.L. (2000) 'Discipline, Dismissals and Complaints to Employment Tribunals', British Journal of Industrial Relations, 38:4, 533-555

Latreille, P.L. (2010) 'Mediating at Work: Of Success, Failure and Fragility', Acas Research Paper, 06/10.

Latreille, P.L. (2011) 'Workplace Mediation: A Thematic Review of the Acas/CIPD Evidence', Acas Research Paper, 13/11.

Legge, K. (1995) HRM: rhetoric, reality and hidden agendas in John Storey (ed.) Human Resource Management: a Critical Text, London: Routledge

Lewin, D. (1999) Theoretical and Empirical Research on the Grievance Procedure and Arbitration: a Critical Review, in A.E. Eaton \& J. Keefe (Eds.), Employment Dispute 
Resolution and Worker Rights, University of Ilinois - Champaign-Urbana: Industrial Relations Research Association: 85-104

Lewin, D. (2001) IR and HR Perspectives on Workplace Conflict: What Can Each Learn From the Other? Human Resource Management Review, 11: 453-485

Lewin, D. (2004) Dispute Resolution in Nonunion Organizations: Key Empirical Findings,” in Alternative Dispute Resolution in the Employment Arena, Estreicher, S. \& Sherwin, D. (eds.), New York: Kluwer, 379-403

Lipsky, D. B., Seeber, R. L., and Fincher, R. D. (2003) Emerging Systems for Managing Workplace Conflict: Lessons from American Corporations for Managers and Dispute Resolution Professionals. San Francisco: Jossey-Bass

Lipsky, D.B., and Avgar, A.C. (2004) Research on Employment Dispute Resolution: Toward a New Paradigm Conflict Resolution Quarterly, 22: 175 - 189

Lipsky, D.B., Avgar, A., Lamare, J.Ryan and Gupta, A. (2014) Conflict Resolution in the United States in W. K. Roche, P. Teague and A.J. S. Colvin, The Oxford Handbook of Conflict Management in Organizations, Oxford, Oxford University Press.

Lynch, J.F. (2001) Beyond ADR: a Systems Approach to Conflict Management Negotiation Journal, 17: 207-16.

MacLeod D and Clarke N. (2009) Engaging for Success: enhancing performance through employee engagement. A Report to Government. London, Department for Business, Innovation and Skills

Marchington M. and Grugulis I. (2000) Best practice human resource management: perfect opportunity or dangerous illusion? The International Journal of Human Resource Management 11: $1104-1124$

Marchington, M. (2009) Where next for HRM? Rediscovering the heart and soul of people management. Institute for Employment Studies, Sussex University 40th Anniversary Paper, Brighton

Maxwell, G.A. and Watson, S. (2006) Perspectives on line managers in human resource management: Hilton International's UK hotels. .International Journal of Human Resource Management, 17: pp 152-1170

McAndrew, I., (2012) Collective bargaining interventions: contemporary New Zealand experiments. International Journal of Human Resource Management 23: pp 495-510

McGovern, P, Gratton, L., Hope-Hailey, V. and Truss, C. (1997) Human resource management on the line? Human Resource Management Journal, 7: 12-29 
Metcalf, David and Milner, S. (1991) A century of UK strike activity: an alternative perspective. CEPDP, 22. Centre for Economic Performance, London, UK

Nesbit, R., Nabatchi, T. and Blomgren Bingham, T. (2012) Employees, Supervisors, and Workplace Mediation: Experiences of Justice and Settlement, Review of Public Personnel Administration, 32:3: 260-287

Paauwe, J., Wright, P. and Guest, D. (2013) HRM and performance: what do we know and where should we go? in J. Paauwe, D. Guest, and P. Wright (eds) HRM and Performance: Achievements and Challenges, Chichester, Sussex: Wiley: 1-13

Piore, M. (2011) Whither Industrial Relations: Does It Have a Future in Post-Industrial Society,” British Journal of Industrial Relations, 49: 4: 792-801

Podsakoff, P. M., MacKenzie, S. B., Paine, J. B., \& Bachrach, D. G. (2000) Organizational citizenship behaviors: a critical review of the theoretical and empirical literature and suggestions for future research. Journal of Management, 26: 513 - 563

Pfeffer, J. (2007) Human Resources from an Organizational Behavior Perspective: Some Paradoxes Explained. Journal of Economic Perspectives, 214: 115-134

Purcell, J. and Hutchinson, S. (2003) Bringing policies to life: the vital role of front-line managers in people management. London: Chartered Institute of Personnel and Development.

Purcell J and Hutchinson S. (2007) Front-line managers as agents in the HRM-performance causal chain: theory, analysis and evidence. Human Resource Management Journal, 17: 3-20

Purcell J. (2010) Individual Disputes at the Workplace: Alternative Dispute Resolution, Dublin: European Foundation for the Improvement of Living and Working Conditions.

Purcell J. (2014a), Line Managers and Workplace Conflict, in W. K. Roche, P. Teague and A.J. S. Colvin, The Oxford Handbook of Conflict Management in Organizations, Oxford, Oxford University Press: 233-249

Purcell, J. (2014b), Disengaging from engagement. Human Resource Management Journal, 24:2: 241-254

Renwick, D. (2003) Line manager involvement in HRM: an inside view, Employee Relations, 25: $262-280$.

Roche W. K. and Teague, P. (2011) Firms and Innovative Conflict Management Systems in Ireland, British Journal of Industrial Relations, Vol. 29: 3: 436-459

Roche, W. K., Hann, D. and Teague P., (2012) The diffusion of alternative dispute resolution practices in Ireland, Economic and Industrial Democracy, Vol. 33: 4: 581-604 
Roche, W. K. and Teague P. (2012) Do Conflict Systems Matter? Human Resource Management, 51: 2:231-258

Roche, W. K. and Teague P. (2014) Conflict Management Systems, in W. K. Roche, P. Teague and A.J. S. Colvin, The Oxford Handbook of Conflict Management in Organizations, Oxford, Oxford University Press: 250-274

Rowe, M. and Bendersky, C. (2003) Workplace justice, zero tolerance and zero barriers. In T.A. Kochan and D. Lipsky (Eds.), Negotiations and change: from the workplace to Society, Ithaca: Cornell University Press: 117-140

Rowe, M. P. (2007) Dispute Resolution in the Non-Union Environment: An Evolution Towards Integrated Systems for Conflict Management? in S. E. Gleason (ed), Workplace Dispute Resolution: Directions for the Twenty-First Century. East Lansing, Mich.: Michigan State University Press: 79-106

Rubinstein, S. and Kochan, T.A. (2001) Learning from Saturn: Possibilities for Corporate Governance and Employee Relations, Ithaca: Cornell University Press.

Rouleau, L. (2005) Micro-Practices of Strategic Sensemaking and Sensegiving: How Middle Managers Interpret and Sell Change Every Day, Journal of Management Studies, 42: 1413-1443

Saundry, R., Jones, C. and Antcliff, V. (2011) 'Discipline, representation and dispute resolution - exploring the role of companions in workplace discipline', Industrial Relations Journal, 42:2: 195-211

Saundry, R., McArdle, L. and Thomas , P. (2013) 'Reframing workplace relations? Conflict resolution and mediation in a Primary Care Trust’, Work, Employment and Society, 27:2, 213231.

Saundry, R. and Wibberley, G. (2012a) 'Mediation and informal resolution - a case study in conflict management', Acas Research Paper, 12/12.

Saundry, R. and Wibberley, G. (2012b) 'Managing individual conflict in the private sector: A case study’, Acas Research Paper, 5/12.

Saundry, R., Bennett. T and Wibberley, G. (2013) 'Workplace mediation: the participant experience', Acas Research Paper, 2/13.

Saundry R., Latreille P., Dickens L., Irvine C., Teague, P., Urwin P., and Wibberley, G. (2014) Reframing Resolution - Managing Conflict and Resolving Individual Employment Disputes in the Contemporary Workplace, ACAS Policy Discussion Papers

Sparrow, P. (2013) Strategic HRM and employee engagement in C Truss, K Alfes, R Delbridge, A Shantz \& E Soane (eds), Employee engagement in theory and practice. Routledge, London:

99-115 
Sydow, J., Schreyögg, G. and Koch, J. (2009) Organizational path dependence: Opening the black box. Academy of Management Review 34: 689-709.

Teague, P. and Roche, W. (2012) Line managers and the management of workplace conflict: evidence from Ireland. Human Resource Management Journal, 22:2: 235-251.

Teague, P., Roche, W. and Hahn, D. (2012) The diffusion of alternative dispute resolution practices in Ireland. Economic and Industrial Democracy, 33: 4: 581-604,

Truss, C., Soane, E., Kerstin , A. and Delbridge, R. (2013) Employee engagement, organisational performance and individual well-being: exploring the evidence, developing the theory. The International Journal of Human Resource Management 24: 2657-2669

Ulrich, D. (1997) Human Resource Champions: The Next Agenda for Delivering Value and Delivering Results, Boston: Harvard Business School Press

Urwin, P., Latreille P. and Karuk V. (2012) Quantitative evidence in the evaluation of ADR: the case of judicial mediation in UK Employment Tribunals. International Journal of Human Resource Management 23: 2: 567-589

Ury, W.L., Brett, J.M. and Goldberg, S.B. (1988) Getting Disputes Resolved: Designing Systems to Cut the Costs of Conflict, Cambridge Mass.: The Program on Negotiation at Harvard Law School. Jossey-Bass, San Francisco, CA.

Van Gramberg, B. (2006) Managing Workplace Conflict: Alternative Dispute Resolution in Australia, Sydney: The Federation Press.

Weick, K., Sutcliffe, K. M., and Obstfeld, D. (2005) Organizing and the process of sensemaking. Organization Science, 16: 409-421

Whittaker, S and Marchington, M. (2003) Employee Relations; Delegating HR responsibility to the line: Threat, opportunity or partnership? Employee Relations, 25: 245-261

Williams, M. (2011) 'Workplace Conflict Management: Awareness and use of Acas code of practice and workplace meditation-A poll of business', Acas Research Papers, 08/11

Wood, S., Saundry R., and Latreille P. (2014) Analysis of the nature, extent and impact of grievance and disciplinary procedures and workplace mediation using WERS2011, ACAS Research Paper 10/14

Wright, P.M., McMahan G.C., Snell S.A. and Gerhart B. (2001) Comparing Line and HR Executives' Perceptions of Human Resource Effectiveness: Service, Roles and Contributions. Human Resource Management, 40: 111-123.

Zack, A. M. (1997) Can Alternative Dispute Resolution Help Resolve Employment Disputes? International Labour Review, 136: 95-108 
Table 1 Conflict Management Practices

\section{Conventional}

Conflict

Involving

\section{Conflict}

Involving

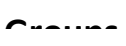

- Formal written grievance \& disciplinary procedures involving progressively higher levels of management in resolving disputes

- Formal written disputes procedures involving progressively higher levels of management in resolving disputes.

- Resort at final stage where deadlock remains to state-provided agencies for conciliation and adjudication
ADR

- Open-door policies

- 'Speak-up' \& related systems

- Mediation

- Ombudsman

- External and internal experts/mediators

- Review panels of managers or peers

- Employee advocates

- Arbitration

- 'Assisted bargaining/mediation within procedure to avoid impasse

- 'Brainstorming' \& related techniques

- 'Interest-based bargaining' with facilitation

- Private arbitration

- Intensive communications surrounding change management 
Figure 1: HRM and the Four Workplace Conflict Management Pathways

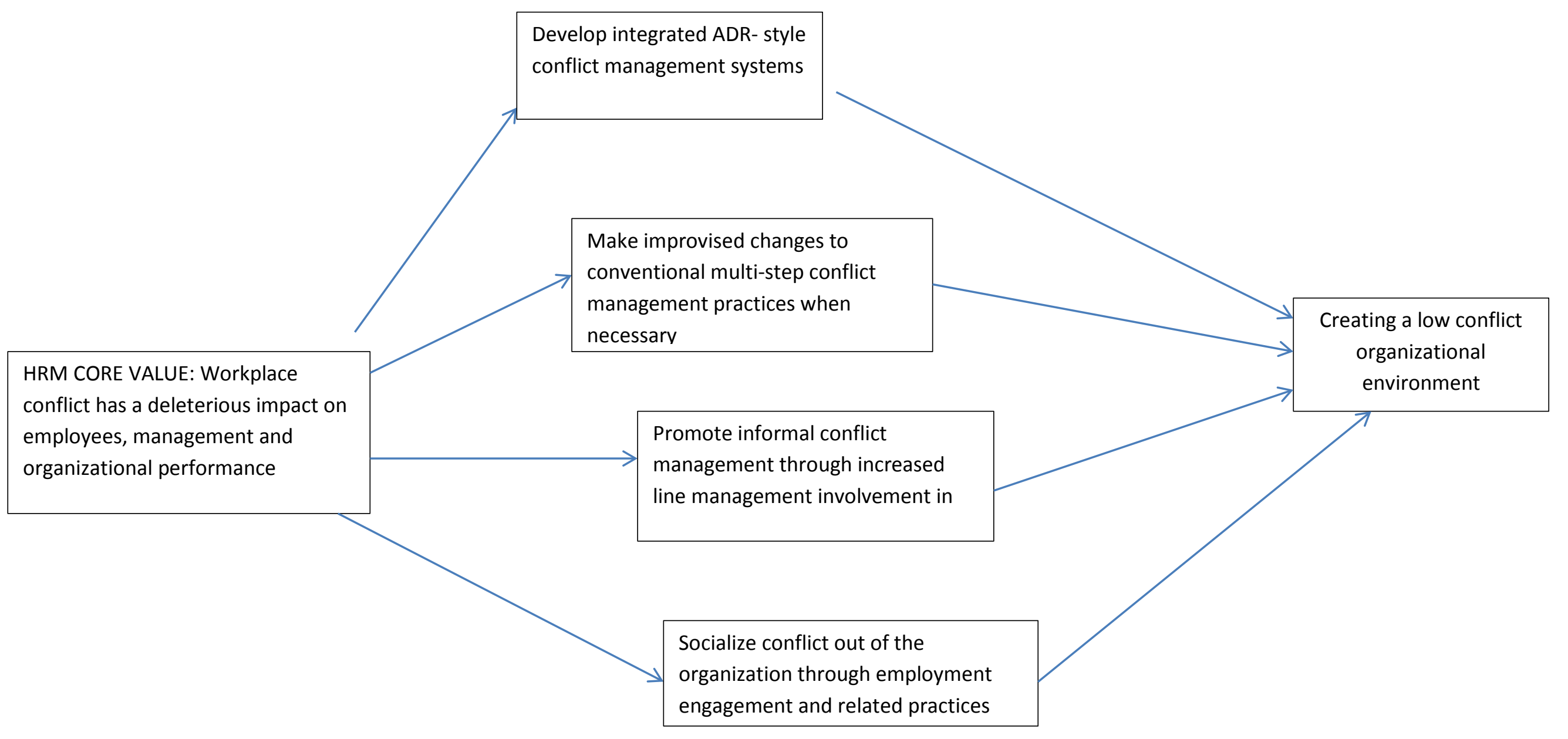

